\title{
Remediation of Heavy Metals from Galvanic Wastewater Using Cow Bone Char as Low Cost Adsorbent
}

\author{
R. A. Olaoye*, S. O. Ojoawo, O. Bamigbade, N. Alimi, I. O. Rasaq, T. Oladejo
}

Department of Civil Engineering, Ladoke Akintola University of Technology, Ogbomoso, Oyo State, Nigeria

\section{PAPER INFO}

\section{Paperhistory:}

Received 11 June 2021

Accepted in revised form 07 November 2021

Keywords:

Adsorption

Cow bone

Galvanized wastewater

Heavy metals

Removal efficiency

\section{$A B S T R$ R A $C$ T}

The adhesion of metal ions from wastewater to surface of a material in an adsorption process had proven to be effective for remediation of wastewater before discharge. There is a growing demand to utilize alternative low-cost adsorbents for the removal of heavy metals from galvanic wastewater in most developing countries. Cow bones are cheap, readily available and can be sourced locally from slaughterhouses and abattoir. Therefore, their use as an alternative adsorbent for remediation of galvanic wastewater had to be assessed. In this study, the efficacy of cow bone char (CBC) was assessed for simultaneous heavy metal ions removal from real life galvanic wastewater in a competitive adsorption process. The galvanic wastewater was characterized using atomic adsorption spectrophotometry while the CBC was characterized using X-ray Fluorescence (XRF), Scanning Electron Microscopy (SEM) and Fourier Transform Infrared (FTIR). Batch experiment was performed to determine the effect of adsorbent dose, contact time and agitation speed on the removal efficiency of heavy metal ions from the galvanized wastewater. The concentrations of $\mathrm{Mn}^{2+}, \mathrm{Fe}^{2+}, \mathrm{Zn}^{2+}, \mathrm{Pb}^{2+}$ and $\mathrm{Cr}^{2+}$ in the raw wastewater exceeded the WHO and EPA standards. The adsorbent revealed a significant distribution of well-developed porous, rough surfaces with cracks characterized by different functional groups for the efficient adsorption process. The optimum adsorbent dose for all the metal ions was $0.04 \mathrm{~g} / 100 \mathrm{~mL}$ at an optimum contact time of 60 minutes except for $\mathrm{Fe}^{2+}$ with optimum contact time of 20 minutes, and agitation speed of $150 \mathrm{rpm}$. The maximum metal removal efficiencies obtained for $\mathrm{Mn}^{2+}, \mathrm{Fe}^{2+}, \mathrm{Zn}^{2+}, \mathrm{Pb}^{2+}$ and $\mathrm{Cr}^{2}$ were $99.7 \%, 100 \%, 99 \%, 90 \%$ and $85 \%{ }^{+}$, respectively. The average adsorption capacity for $\mathrm{Mn}^{2+}, \mathrm{Fe}^{2+}, \mathrm{Zn}^{2+}, \mathrm{Pb}^{2+}$ and $\mathrm{Cr}^{2+}$ were 0.44 $\mathrm{mg} / \mathrm{g}, 26.7 \mathrm{mg} / \mathrm{g}, 78.5 \mathrm{mg} / \mathrm{g}, 0.133 \mathrm{mg} / \mathrm{g}$ for and $10.36 \mathrm{mg} / \mathrm{g}$, respectively. CBC offers efficient and cost-effective removal of selected metal ions from galvanized wastewater.

doi: $10.5829 /$ ijee.2021.12.04.05

\section{INTRODUCTION}

Galvanized wastewater is one of the highly rated toxic wastewater because of its heavy metal contents, organic substances and surfactants, and can be considered among the most polluting wastewater difficult to treat. Therefore, requires special treatment in order to reduce the pollutants' concentration before disposal [1-3]. Indiscriminate disposal of galvanized wastewater into the environment contaminates the soil, surface and groundwater and it has been reported to be one of the leading activators of cancer and cardiovascular diseases in man as well as contributor to other negative health conditions like brain damage, lethargy, neurological signs etc. $[4,5]$. Galvanization or galvanizing is the process of applying a protective zinc coating to steel or iron, to prevent rusting, improve wear resistance or for ornamental purposes [3]. It consists of sequential electrochemical processes resulting in wastewater generation of different composition $[3,6]$. There are two widely known processes; the hot-dip galvanization and the cold galvanization $[6,7]$. The most common method is hot-dip galvanizing, in which the metal parts are submerged in a bath of molten hot zinc [6,8]. Cold

*Corresponding Author Email: raolaoye@lautech.edu.ng (R. A. Olaoye)

Please cite this article as: R. A. Olaoye, S. O. Ojoawo, O. Bamigbade, N. Alimi, I. O. Rasaq, T. Oladejo, 2021. Remediation of Heavy Metals from Galvanic Wastewater Using Cow Bone Char as Low Cost Adsorbent, Iranian (Iranica) Journal of Energy and Environment, 12 (4), pp. $318-326$. Doi: $10.5829 /$ ijee.2021.12.04.05 
galvanization has three main phases:surface preparation, galvanizing and post treatment, each phase involving the use of rinsing tanks with water and are often loaded with high concentrations of heavy metals which are often disposed indiscriminately [8]. One of the primary producers of toxic compounds into the environment is improper discharge of galvanic wastewater. More often focus has been placed on the galvanic sludge produced during treatment of the wastewater, however, if the wastewater is adequately treated, less of the sludge will be generated and the environment would remain safe.

Several techniques had been employed for the treatment of galvanized wastewater, these include chemical coagulation/flocculation, microfiltration, ultrafiltration, nano-filtration, reverse osmosis, chelating, polyelectrolytes, ionic exchange - electric arc furnace [3$5,9]$. Most of these techniques are slow, as sociated with high consumption of reagents and generation of sludge that require disposal in a special engineered landfill which often result in high cost, considerable investment and operating costs, some require large processing areas [2]. The use of locally sourced agricultural by-products like moringa, orange peel, cassava peel, orange peel, banana peel, plum leaves, guava fruits etc. [10, 11], natural clay minerals [12], composite nano-fibrous material [13] and carbon as materials for adsorbent have gained wide application for the removal of pollutants and heavy metals.

Presently, there is paucity of research on the use of animal bone for remediation of heavy metals from real time galvanic wastewater. Among the various carbonaceous materials used as absorbent, animal/ cowbone had been reported to be effective for removing a variety of pollutants, such as heavy metals and dyes from aqueous solutions due to its high surface area, welldeveloped internal micro-porosity, and a broad spectrum of surface functional groups [14]. Globally, increasing demand for meat has resulted in the generation of large amounts of cow-bone waste $[15,16]$. One of the ways to manage this excessive bone wastage is conversion to a usable product as adsorbent because of its availability, low or no cost, versatility, low energy requirement and sustainability in usage. Previous studies had reported the effective use of cow bone for wastewater remediation. Cow bone had been adopted for the removal of methylene blue from aqueous solution [17]. Adsorption of hexavalent chromium from aqueous solution using cow bone had als o been reported [18]. Adsorption of selected metal ions; iron, zinc, lead and manganese from cassava wastewater using cow bone had been reported to give excellent removal efficiency between $93 \%$ and $99 \%$ for $\mathrm{Fe}^{2+}, \mathrm{Zn}^{2+}, \mathrm{Pb}^{2+}$ and $\mathrm{Mn}^{2+}[5]$. Little is known on the efficacy of cow bone for galvanic wastewater remediation.

Several work had been carried out on the treatment or remediation of galvanized wastewater using various techniques. Liquid surfactant membrane technique was utilized to reduce $\mathrm{Cr}$ (VI) and $\mathrm{Zn}$ (II) from galvanized wastewater [19]. Coagulants and flocculants in a system of Jar-test have been used to remediate galvanized wastewater [5], these techniques are slow with large amounts of sludge production. Natural adsorbents had been utilized to remediate iron and chloride from wastewater achieved removal efficiency of $72 \%$ and $54 \%$, respectively [20]. Magnetic nanoparticles had been utilized to obtain $95 \%$ of $\mathrm{Zn}^{2+}$ removal from galvanic wastewater [21]. Electric spark method using metal loading (Fe, Al) and low-voltage (up to $1000 \mathrm{~V}$ ) equipment had been employed reduce the concentrations of $\mathrm{Zn}^{2+}, \mathrm{Cr}^{6+}, \mathrm{Cr}^{3+}, \mathrm{Cu}^{2+}$ from multicomponent galvanic wastewater [2]. These turned out to be economically inexpedient due to high cost and limited resource of high -voltage equipment, increased danger and low process productivity. Hence, most of the methods employed by these studies are expensive, requiring considerable investment and operating cost as well as large processing areas. Several commercially available activated carbons have also been identified for use as adsorbent as stated earlier especially in the removal of heavy metals from industrial wastewater. Nevertheless, these processes are also proven to be expensive. There is a growing demand to utilize alternative low-cost available adsorbents for the removal of heavy metals $[4,22]$ from galvanic wastewater. Cow bones are cheap and readily available locally from slaughterhouses and abattoir. Therefore, their use as an alternative adsorbent for remediation of galvanic wastewater had to be assessed.

In this study, the efficacy of cow bone char was assessed for simultaneous heavy metal ions removal from real life galvanic wastewater in a competitive adsorption process and not from synthesized aqueous wastewater solution.

\section{MATERIALS AND METHODS}

All the chemicals and reagents used were of analytical grade. The experiments were performed following standard method procedures.

\section{Characterization of galvanized wastewater}

The galvanized wastewater was obtained from a Machine Tools factory located on 110 hectares industrial site, South Western Nigeria $\left(7.839043^{\circ} \mathrm{N}, 4.602833^{\circ}\right.$ E). The raw wastewater was characterized for heavy metal content following standard procedures described in the standard method for examination of water and wastewater [23]. The initial $\mathrm{pH}$ of the galvanized wastewater was 5.9 and was adjusted to 7.0 using dilute solutions of $\mathrm{NaOH}$ throughout the experiments. Firstly, the digestion of the galvanized wastewater sample was carried out with the aim of breaking down the complexity of the samples before using the Atomic Absorption Spectrophotometer (No. PG6990). A $10 \mathrm{~mL}$ of the galvanized wastewater 
sample was introduced into a $50 \mathrm{~mL}$ beaker and $10 \mathrm{~mL}$ of concentrated nitric acid was carefully added to it. The beaker was placed inside the fume cupboard and heated with the heating mantle for 30 minutes at $100^{\circ} \mathrm{C}$. The cooled mixture was removed from the fume cupboard. Distill water was added to make it up to $100 \mathrm{~mL}$ before it was filtered and the filtrate was subjected to Atomic Absorption Spectrophotometer (AAS) analys is [23].

\section{Preparation of cow bone and characterization of cow bone char}

Cow bones were obtained from the abattoir Market, in Ogbomoso $\left(8.1447^{\circ} \mathrm{N}, 4.2426^{\circ}\right.$ E), Southwestem Nigeria. Fresh cow bones obtained were boiled in hot water to tenderize the meat for easy removal of leftover flesh on the bone and washed to remove impurities on the surfaces. The bones were sundried, crushed and were carbonized inside a muffle furnace at $800^{\circ} \mathrm{C}$ for 5 hours. The bone charred produced were further reduce by grinding using ceramic ball mill grinded and was sieved with $125 \mu \mathrm{m}$ sieve to obtain the fine powdered form. The method for the preparation of the cow bone char is as stated in our previous work [14]. Characterization of the cow bone char was performed in accordance to procedures outlined in the Association of Official Analytical Chemist (AOAC) [24]. The adsorbents produced were characterized by physical and chemical properties. The elemental content of the adsorbent was determined with X-ray Fluorescence (XRF), Scanning Electron Microscope (SEM, model: JEOL JSM-6380LA) was employed to determine the surface morphology of the adsorbent while Fourier transform infrared spectrometer FTIR (Perkin Elmer) was used to determine the characteristics of the functional groups on the adsorbent surface as outlined in our previous work [14].

\section{Batch experiment procedure}

The batch experiment was performed in triplicates in accordance to the steps outlined in previous study $[2,14]$.

Variation of absorbent dose was performed using four conical flasks of $250 \mathrm{~mL}$ labeled 1 to 4 . In each of the flasks $100 \mathrm{~mL}$ of the galvanized wastewater was added and $0.02,0.04,0.06$ and $0.08 \mathrm{~g}$ of the $\mathrm{CBC}$ was added to the four respective conical flasks. The flasks were then placed in a rotary mechanical shaker and agitated at a speed of $150 \mathrm{rpm}$ for 60 minutes. The filtrate from each flask was collected and subjected to AAS to determine the heavy metal concentrations. Contact time effect was performed using six conical flasks with $100 \mathrm{~mL}$ of the galvanized wastewater to which $0.02 \mathrm{~g}$ of adsorbent was added into each. The flasks were then placed in a mechanical shaker and agitated at $150 \mathrm{rpm}$ for different selected contact times of 20,40,60, 80, 100 and 120 minutes. Filtrates from the content of each flask were subjected to AAS analysis. Effect of agitation rate was performed to determine its effect on the treatment process, $0.02 \mathrm{~g}$ each of the adsorbent was added to 4 conical flasks of $100 \mathrm{~mL}$ of the galvanized wastewater. The conical flasks were placed in a mechanical shaker in turns and rotated at the selected speed ranging from 50 to $200 \mathrm{rpm}$ at intervals of $50 \mathrm{rpm}$ at a constant time of 60 minutes. The percentage of metal removal efficiency was estimated using Equation (1):

$$
\text { Removal efficiency }(\%)=\frac{C_{1}-C_{2}}{C_{1}} \times 100
$$

where $C_{1}=$ Initial concentration of heavy metals in the wastewater

$\mathrm{C}_{2}=$ Final concentration of heavy metals in the wastewater

\section{RESULT AND DISCUSSION}

Heavy metal content of the galvanized wastewater

The mean concentrations of $\mathrm{Mn}^{2+}, \mathrm{Pb}^{2+}, \mathrm{Zn}^{2+}, \mathrm{Fe}^{2+}$ and $\mathrm{Cr}^{2+}$ in the raw galvanic wastewater are presented in Table 1 against the World Health Organization (WHO) and Environmental Protection Agency (EPA) standards. The observed mean concentration of $\mathrm{Mn}^{2+}, \mathrm{Pb}^{2+}, \mathrm{Zn}^{2+}$, $\mathrm{Fe}^{2+}$ and $\mathrm{Cr}^{2+}$ in the wastewater were $0.185 \mathrm{mg} / \mathrm{L}, 0.079$ $\mathrm{mg} / \mathrm{L}, \quad 31.859 \mathrm{mg} / \mathrm{L}, \quad 10.848 \mathrm{mg} / \mathrm{L}$ and $5.23 \mathrm{mg} / \mathrm{L}$. respectively; which is higher than WHO and EPA permissible limits. High concentration of metal ions above the threshold was also reported by Beh et al. [4] for iron, zinc and manganese in galvanic wastewater similarly, high concentration for zinc and iron in galvanized wastewater was reported by Berradi et al. [5].

\section{Ads orbent characterization}

The physical and chemical properties of the cow-bone char are presented in Table 2. This result is in line with cow bone charcoal reported in previous studies [25, 26]. Figure 1( $a$ and $b$ ) presents different magnification of SEM images for the adsorbent. The adsorbent was crystalline in nature, its surface morphology revealed a significant distribution of well-developed porous and rough surface with crack for the efficient adsorption process. Adsorbent pores provide an effective surface for ions to be adsorbed in the wastewater. Figure 1 revealed that the absorbent has good porosity which allows for the adsorption of heavy metals.

Table 1. Mean concentrations of the heavy metals in the galvanized wastewater

\begin{tabular}{lccc}
\hline Metals & $\begin{array}{c}\text { Concentration }(\mathbf{m g} / \mathbf{L}) \\
\text { mean } \pm \text { SD }\end{array}$ & $\begin{array}{c}\text { WHO } \\
(\mathbf{m g} / \mathbf{L})\end{array}$ & EPA \\
\hline Manganese $(\mathrm{Mn})$ & $0.185 \pm 0.0092$ & 0.05 & 0.05 \\
Lead $(\mathrm{Pb})$ & $0.079 \pm 0.0075$ & 0.015 & 0.01 \\
Zinc $(\mathrm{Zn})$ & $31.859 \pm 0.0577$ & 5 & 5 \\
Iron $(\mathrm{Fe})$ & $10.848 \pm 0.069$ & 0.3 & 0.3 \\
Chromium $(\mathrm{Cr})$ & $5.23 \pm 0.057$ & & 0.1 \\
\hline
\end{tabular}


Table 2. Phy sicochemical properties of the absorbent

\begin{tabular}{lc}
\hline Parameters & \begin{tabular}{c} 
Mean $\begin{array}{c} \pm \text { standard deviation of } \\
\text { triplicate evaluation }\end{array}$ \\
\hline Moisture $(\%)$
\end{tabular} \\
Volatile matter $(\%)$ & $1.73 \pm 0.1$ \\
Fixed carbon $(\%)$ & $24.71 \pm 0.27$ \\
Surface area $\left(\mathrm{m}^{2} / \mathrm{g}\right)$ & $1.92 \pm 0.009$ \\
Pore volume $\left(\mathrm{cm}^{3} / \mathrm{g}\right)$ & $0.013 \pm 0.001$ \\
Carbon $(\%)$ & $25 \pm 0.03$ \\
Nitrogen $(\%)$ & $1.5 \pm 0.1$ \\
Hydrogen $(\%)$ & $3.27 \pm 0.09$ \\
CaCO & $(\%)$ \\
Sulphur $(\%)$ & $51.87 \pm 0.19$ \\
Source: Previous work of Olaoyeet al. [14]
\end{tabular}

The FTIR spectra [14] revealed several peaks; 3981.6 , 3645.5 - 3547.4, 3433.8 - 3321.5, 3237.1- 3049.4, 2944.8$2833.7, \quad 2728.5-2571.5, \quad 2411.9-2150.4, \quad 2065.5$ 1613.6, 1369.1 - 1280.2, $1006.2-878.5,761.3 \mathrm{~cm}^{-1}$ etc. representing the presence of different functional groups like alcohol (O-H stretch, $\mathrm{H}$-bonded, free), alkane $(\mathrm{C}-\mathrm{H}$ stretch, $-\mathrm{C}-\mathrm{H}$ bending) alkene $(=\mathrm{C}-\mathrm{H}$ bending, $\mathrm{C}=\mathrm{C}$ stretch) amides (N-H stretch) nitro compounds (N-O stretch) acid (O-H, stretch) ester (C-O, stretch). These functional group play a vital role in the ad sorbent property for adsorption process.

\section{Adsorption process}

It was observed that the concentration of metal ions reduces with adsorbent dose, contact time and speed of agitation as compared with the initial concentration of the raw wastewater as shown in the stacked column in Figure 2.

As the adsorbent dose was increased from $0.02-$ $0.04 \mathrm{~g}$ the concentration of metal ions reduces. Further
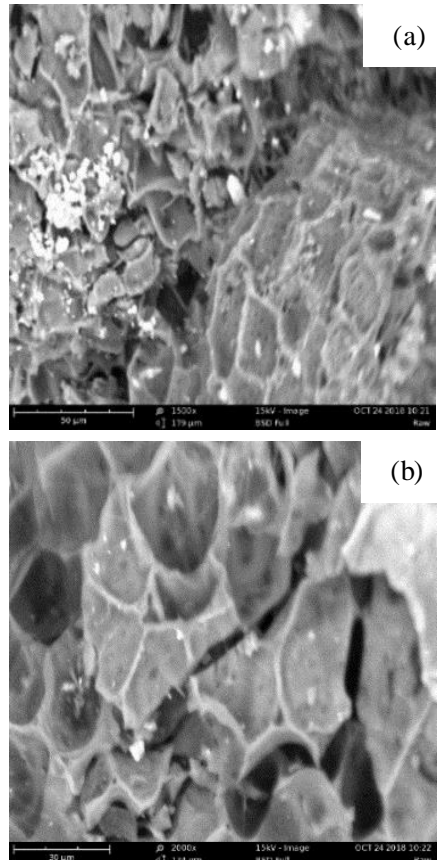

Figure 1. SEM images of the CBC. Magnification (a) 1500x, (b) 2000x

increase of adsorbent, slows down the reduction of metal ions in the solution. The average concentrations at adsorbent doses of $0.02 \mathrm{~g}$ were $0.002,0.08,1.10,0.008$ and $1.39 \mathrm{mg} / \mathrm{L}$ for $\mathrm{Mn}^{2+}, \mathrm{Fe}^{2+}, \mathrm{Zn}^{2+}, \mathrm{Pb}^{2+}$ and $\mathrm{Cr}^{2+}$, respectively. These concentration values reduced to $0.001,0.035,0.030,0.007$ and $1.29 \mathrm{mg} / \mathrm{L}$ at adsorbent dose of $0.04 \mathrm{~g}$ before an increase was observed between adsorbent doses of $0.06-0.08 \mathrm{~g}$ with average metal concentrations between $0.002-0.003,1.17-2.07,0.32$ $0.33,0.009-0.01$ and $1.58-1.61 \mathrm{mg} / \mathrm{L}$ for $\mathrm{Mn}^{2+}, \mathrm{Fe}^{2+}$, $\mathrm{Zn}^{2+}, \mathrm{Pb}^{2+}$ and $\mathrm{Cr}^{2+}$, respectively.

The average concentrations between contact time of 20 - 60 minutes were $0.0009-0.004 \mathrm{mg} / \mathrm{L}$ for $\mathrm{Mn}^{2+}, 0.30$ $0.28 \mathrm{mg} / \mathrm{L}$ for $\mathrm{Zn}^{2+}, 0.04-0.02 \mathrm{mg} / \mathrm{L}$ for $\mathrm{Pb}^{2+}, 1.71$

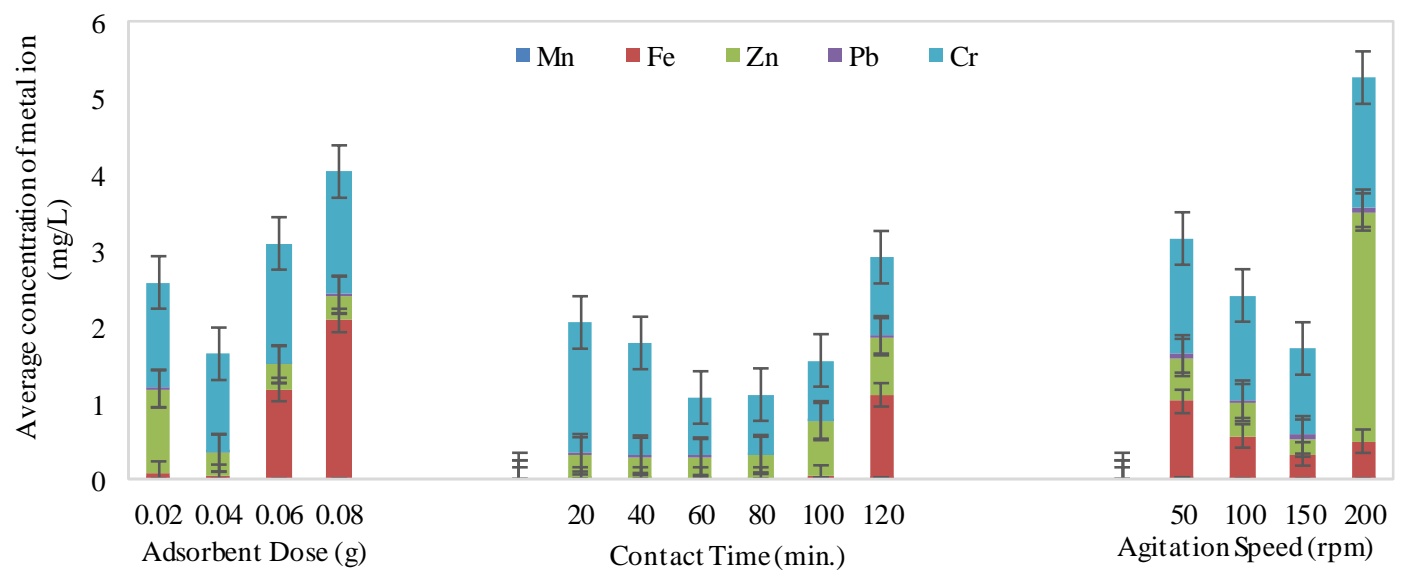

Figure 2. Average concentration of metal ion during the adsorption process 
$0.077 \mathrm{mg} / \mathrm{L}$ for $\mathrm{Cr}^{2+}$ while $\mathrm{Fe}^{2+}$ was not detected. With further increase in contact time between $80-120$ minutes, the observed average metal concentrations were between $0.0007-0.019,0-1.08,0.31-0.76,0.02-$ 0.025 and $0.775-1.02 \mathrm{mg} / \mathrm{L}$ for $\mathrm{Mn}^{2+}, \mathrm{Fe}^{2+}, \mathrm{Zn}^{2+}, \mathrm{Pb}^{2+}$ and $\mathrm{Cr}^{2+}$, respectively. Average concentration values between $0.02-0.002,0.99-0.49,0.58-3.00,0.047-$ 0.049 and $1.51-1.71 \mathrm{mg} / \mathrm{L}$ for $\mathrm{Mn}^{2+}, \mathrm{Fe}^{2+}, \mathrm{Zn}^{2+}, \mathrm{Pb}^{2+}$ and $\mathrm{Cr}^{2+}$, respectively was observed at agitation speed of $50-$ $200 \mathrm{rpm}$. Minimum concentrations were observed at a speed of $150 \mathrm{rpm}$ with average concentration values of $0.002,0.33,0.21,0.04$ and $1.13 \mathrm{mg} / \mathrm{L}$ for $\mathrm{Mn}^{2+}, \mathrm{Fe}^{2+}$, $\mathrm{Zn}^{2+}, \mathrm{Pb}^{2+}$ and $\mathrm{Cr}^{2+}$, respectively.

\section{Effects of adsorbent dose}

The removal efficiency in percentage against adsorbent dose is presented in Figure 3(a). Adsorbent dosage was varied in the order of 0.02 to $0.08 \mathrm{~g}$ at an interval of $0.02 \mathrm{~g}$ for the $100 \mathrm{~mL}$ galvanized wastewater, agitated at 150 rpm for 60 minutes. It was observed that the percentage of metal ion removal increased with increasing dosage of ads orbent until peak adsorption was obtained at adsorbent dose of $0.04 \mathrm{~g}$. Removal efficiency generally increases with increase in adsorbent dose until an equilibrium condition is reached at appropriate temperature after which gradual decrease in adsorption is observed. This trend is expected because as the adsorbent dose increases the number of adsorbent particles in the solution increases and thus more metal ions are attached to their surfaces [27]. All active sites were entirely exposed at lower adsorbent doses, while only a fraction of the active sites were exposed at higher doses [14, 28, 29]. Thus, a higher adsorbent dosage causes aggregation, which decreases the total surface area of adsorbent, leading to gradual decrease [14, 30-32]. Hence the adsorbent dose was fixed at $0.04 \mathrm{~g}$. Maximum metal ion removal expressed as a percentage was $99 \%$ for $\mathrm{Mn}^{2+}, 99.6 \%$ for $\mathrm{Fe}^{2+}, 99.05 \%$ for $\mathrm{Zn}^{2+}, 90.63 \%$ for $\mathrm{Pb}^{2+}$, and $75.23 \%$ for $\mathrm{Cr}^{2+}$, observed at an adsorbent dose of $0.04 \mathrm{~g}$. Hence an optimum dosage of $0.04 \mathrm{~g}$ of Cow Bone Char was adopted for all the adsorption processes. It infers that effective adsorption sites increase with adsorbent doses until a decline after the dose of $0.04 \mathrm{~g}$ was utilized. All adsorbent doses used revealed adsorption efficiency above 95\% except for $\mathrm{Cr}^{2+}$. Adsorbent dose of $0.4 \mathrm{~g} / 100 \mathrm{~mL}$ was reported for $\mathrm{Cd}(\mathrm{II}), \mathrm{Pb}(\mathrm{II}), \mathrm{Zn}(\mathrm{II}), \mathrm{Cr}(\mathrm{III})$ and $\mathrm{Cu}(\mathrm{II})$ adsorption using milled adsorbents of mango peel and Alisma plantago aquatic [33]. Similar results were reported with $5 \mathrm{~g}$ increase of adsorbent dose for $\mathrm{Mn}^{2+}$ removal efficiency between $95.3 \%$ and $95.4 \% \quad[34,35]$. High adsorption (a)

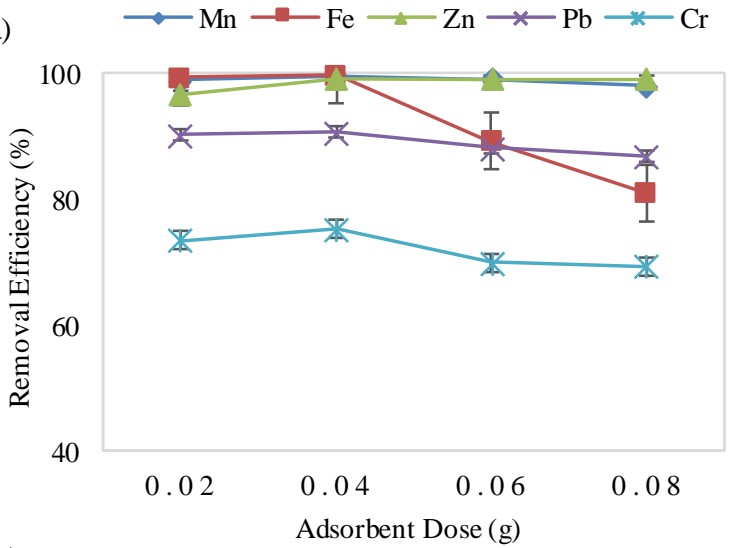

(c)

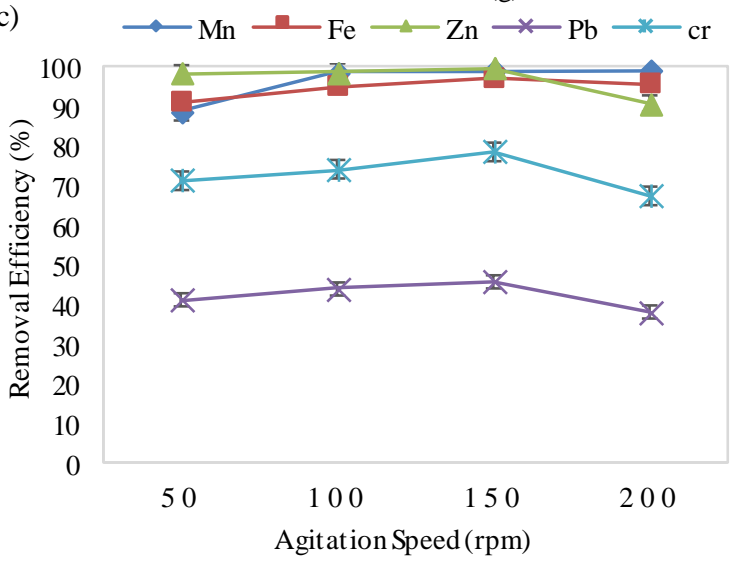

(b)

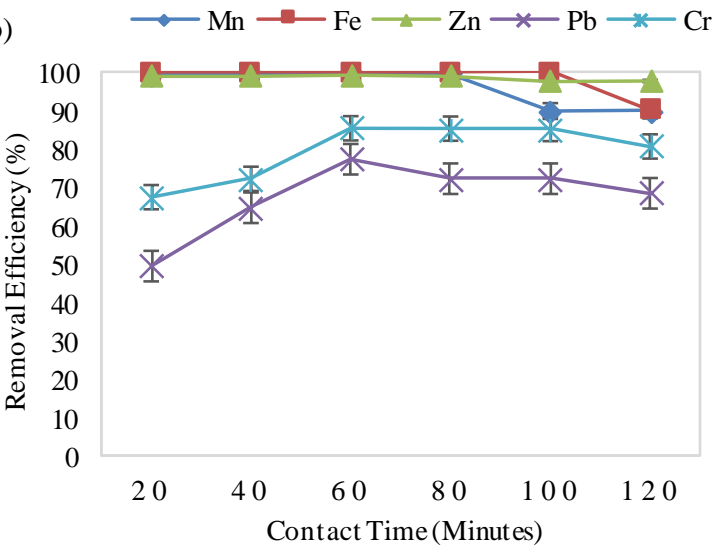

(d)

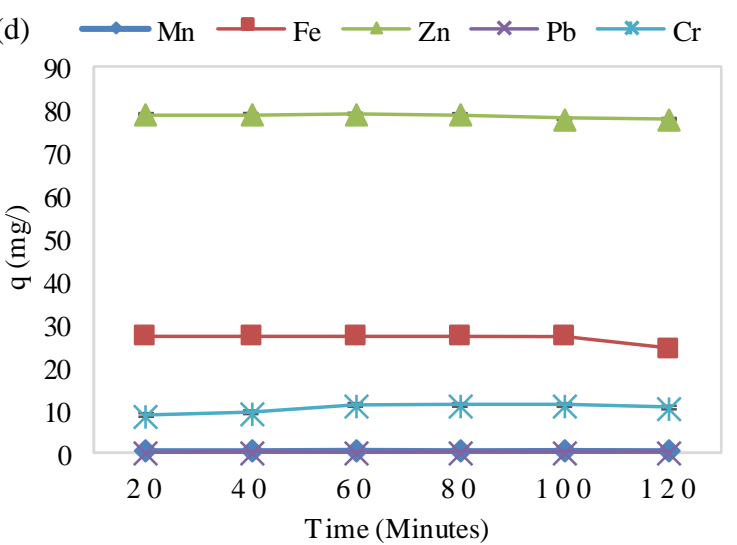

Figure 3. Removal efficiency with (a) adsorbent dose (b) contact time (c) agitation speed (d) metal uptake capacity 
efficiency for adsorbent dosage had been reported to be due to internal structure of the adsorbent and the availability of active sites as well as larger pore spaces [10, 34].

\section{Effects of contact time}

The effect of contact time with metal removal is presented in Figure 3(b). Contact time was varied between 20 - 120 minutes for an adsorbent dose of $0.04 \mathrm{~g}$. Reduction of metal ion removal was observed with an increase in contact time for all the metal ions. It was observed that removal efficiency was rapid initially for $\mathrm{Pb}^{2+}$ and $\mathrm{Cr}^{2+}$ due to presence of available vacant sites which became used up as contact time increases and then decreases gradually until equilibrium time was reached beyond which there was no significant increase in removal rate of the metal ions.

For $\mathrm{Mn}^{2+}, \mathrm{Fe}^{2+}$ and $\mathrm{Zn}^{2+}$ as contact time increases, removal efficiency increases at a constant steady rate until an equilibrium time is reached at 60 minutes after which it decreases and remains constant up to 120 minutes except for $\mathrm{Fe}^{2+}$ which declines after 100 minutes. Removal efficiency increases with increasing contact time until an equilibrium time when it gradually declines. The time required for the equilibrium to be attained for all the metal ions was 60 minutes beyond this contact time; desorption occurs which releases ions that had already been absorbed. Similar results was reported, that at saturation point increasing contact time would reduce the effectiveness of the adsorbent [36]. In this study, removal efficiency obtained varied between $89.9-99.7 \%$ for $\mathrm{Mn}^{2+}, 90-100 \%$ for $\mathrm{Fe}^{2+}, 97-99.12 \%$ for $\mathrm{Zn}^{2+}, 49-77$. $2 \%$ for $\mathrm{Pb}^{2+}$ and $67-85 \%$ for $\mathrm{Cr}^{2+}$. It was observed that increasing contact time has little effect on $\mathrm{Fe}^{2+}$ removal because at 20 minutes of contact the $\mathrm{Fe}^{2+}$ had been completely removed due to availability of active sufficient site for the adsorption process. Adsorption efficiency above $95 \%$ was observed for $\mathrm{Mn}^{2+}, \mathrm{Fe}^{2+}$ and $\mathrm{Zn}^{2+}$ while $77 \%$ and $85 \%$ was recorded for $\mathrm{Pb}^{2+}$ and $\mathrm{Cr}^{2+}$, respectively. Adsorption efficiency of $95 \%$ in less than 10 minutes for only $\mathrm{Zn}^{2+}$ removal from galvanic wastewater using magnetic nanoparticles had been reported by Sawalha et al. [21]. However, despite the simultaneous adsorption of metals in this study $\mathrm{Fe}^{2+}$ removal efficiency was almost $100 \%$. Contact time of 60 minutes had been reported for $\mathrm{Fe}^{2+}, \mathrm{Zn}^{2+}, \mathrm{Pb}^{2+}$, and $\mathrm{Mn}^{2+}$ removal from cassava wastewater [14]. It was reported by Coelho et al. [19] observed removal efficiency of $95 \%$ and $70 \%$ for $\mathrm{Cr}^{6+}$ and $\mathrm{Zn}^{2+}$, respectively from galvanized wastewater between a contact time of 3 to 30 minutes, after which there was slight reduction. Kumar et al. [20] obtained maximum removal efficiency of $72 \%$ at a contact time of 90 minutes, adsorbent dosage of $60 \mathrm{mg} / \mathrm{L}$ for $\mathrm{Fe}^{2+}$ removal in galvanized wastewater. Maximum adsorption of $\mathrm{Cr}^{6+}$ at 35 minutes, $53 \mu \mathrm{m}$ size of adsorbent, and $3 \mathrm{~g}$ of adsorbent dosage was also reported by Sunday et al. [18].
There was also a high increase in the rate of adsorption of $\mathrm{Cr}(\mathrm{VI})$ using tamarind wood activated carbon within 20 minutes, which decreased as the time was increased; thus, attaining equilibrium within 40 minutes [27].

\section{Effects of agitation}

The effects of rotating speed on the metal removal is presented in Figure 3(c). Agitation is an important parameter in adsorption phenomena because it influences the distribution of the solute in the bulk solution and the formation of the external boundary. The speed was varied from $50 \mathrm{rpm}-200 \mathrm{rpm}$ at $50 \mathrm{rpm}$ interval. Increase in removal efficiency of metal ions was observed between agitation speeds of $50 \mathrm{rpm}-150 \mathrm{rpm}$ because as stirring speed increases, the diffusion and mass transfer also increases within the solution before a slight decline at 200 rpm. By increasing the stirring speed turbulence also increases and at the same time the adsorbent reacts more with the wastewater, which aids the adsorption process, however, beyond this contact time, slight decrease was attained. These agree with previous study on the removal of $\mathrm{Cr}$ (VI) using trioctylphosphine oxide (TOPO) and trioctylamine and Alamine 336 as adsorbent [37] where agitation speed was studied in the range of $200-350 \mathrm{rpm}$. The extraction efficiency of $\mathrm{Cr}$ VI increased with increasing speed, optimum mixing speed of $325 \mathrm{rpm}$ resulted in the highest extraction efficiency beyond which leakage of the metal ions into the solution starts which results in gradual decline in metal removal. The decrease was attributed to rupture of the globules by shear forces and swelling which led to loss of solute and removal agent due to the agitation of internal and feed phases thereby decreasing the removal efficiency [37-39].

In this study, mixing speed of $150 \mathrm{rpm}$ was taken as the best speed for the adsorption of metal ions, bey ond this leakages of metals that have already been adsorbed may result due to shearing of the solution thus causing gradual depletion in metal extraction [37]. Maximum adsorption efficiency of $98.7 \%$ was obtained for $\mathrm{Mn}^{2+}$, 96.9\% for $\mathrm{Fe}^{2+}, 99.3 \%$ for $\mathrm{Zn}^{2+}, 45.6 \%$ for $\mathrm{Pb}^{2+}$ and $78 \%$ for $\mathrm{Cr}^{2+}$ was obtained in this study at agitation speed of $150 \mathrm{rpm}$. It can be seen that agitation has the least effect on $\mathrm{Pb}^{2+}$ removal as the active sites for adsorption processes were stable throughout, similar results was reported by Olaoye et al. [14] using Cow bone for metal ion removal.

\section{Ads orption capacity}

The average adsorption capacity for $\mathrm{Mn}^{2+}$ was $0.44 \mathrm{mg} / \mathrm{g}$, $26.7 \mathrm{mg} / \mathrm{g}$ for $\mathrm{Fe}^{2+}, 78.5 \mathrm{mg} / \mathrm{g}$ for $\mathrm{Zn}^{2+}, 0.133 \mathrm{mg} / \mathrm{g}$ for $\mathrm{Pb}^{2+}$ and $10.36 \mathrm{mg} / \mathrm{g}$ for $\mathrm{Cr}^{2+}$ as shown in Figure 3(d). Adsorption capacity between $0.1403-1.551 \mathrm{mg} / \mathrm{g}$ for $\mathrm{Pb}^{2+}$ had been reported [40] using modified melon husk for tannery wastewater treatment while higher adsorption capacity of $85.4 \mathrm{mg} / \mathrm{g}$ for $\mathrm{Pb}^{2+}$ was reported by Ramezani et al. [41] using modified magnetic graphene oxide. 
The coefficient of determination $\left(\mathrm{R}^{2}\right)$ obtained for the adsorption processes were; 0.94 for $\mathrm{Mn}^{2+}, 0.99$ for $\mathrm{Fe}^{2+}$, 0.91 for $\mathrm{Zn}^{2+}, 0.89$ for $\mathrm{Pb}^{2+}$ and 0.78 for $\mathrm{Cr}^{2+}$. $\mathrm{R}^{2}$ values obtained were indicative of sound correlation. $\mathrm{R}^{2}$ values for $\mathrm{Mn}^{2+}, \mathrm{Fe}^{2+}$ and $\mathrm{Zn}^{2+}$ metal ion removal were $>0.9$, subsequently for $\mathrm{Pb}^{2+}$ and $\mathrm{Cr}^{2+}, \mathrm{R}^{2}$ values were $>0.78$. The best fit for metal ions removal efficiency at varying agitation speed as shown in Figure 4 reflect good adsorption properties of the adsorbent. The lines were smooth and continuous, the equations for the indeterminate variable for $\mathrm{Mn}^{2+}, \mathrm{Fe}^{2+}, \mathrm{Zn}^{2+}, \mathrm{Pb}^{2+}$ and $\mathrm{Cr}^{2+}$ are displayed in the equations were second order polynomial equations for each of the metal ions.

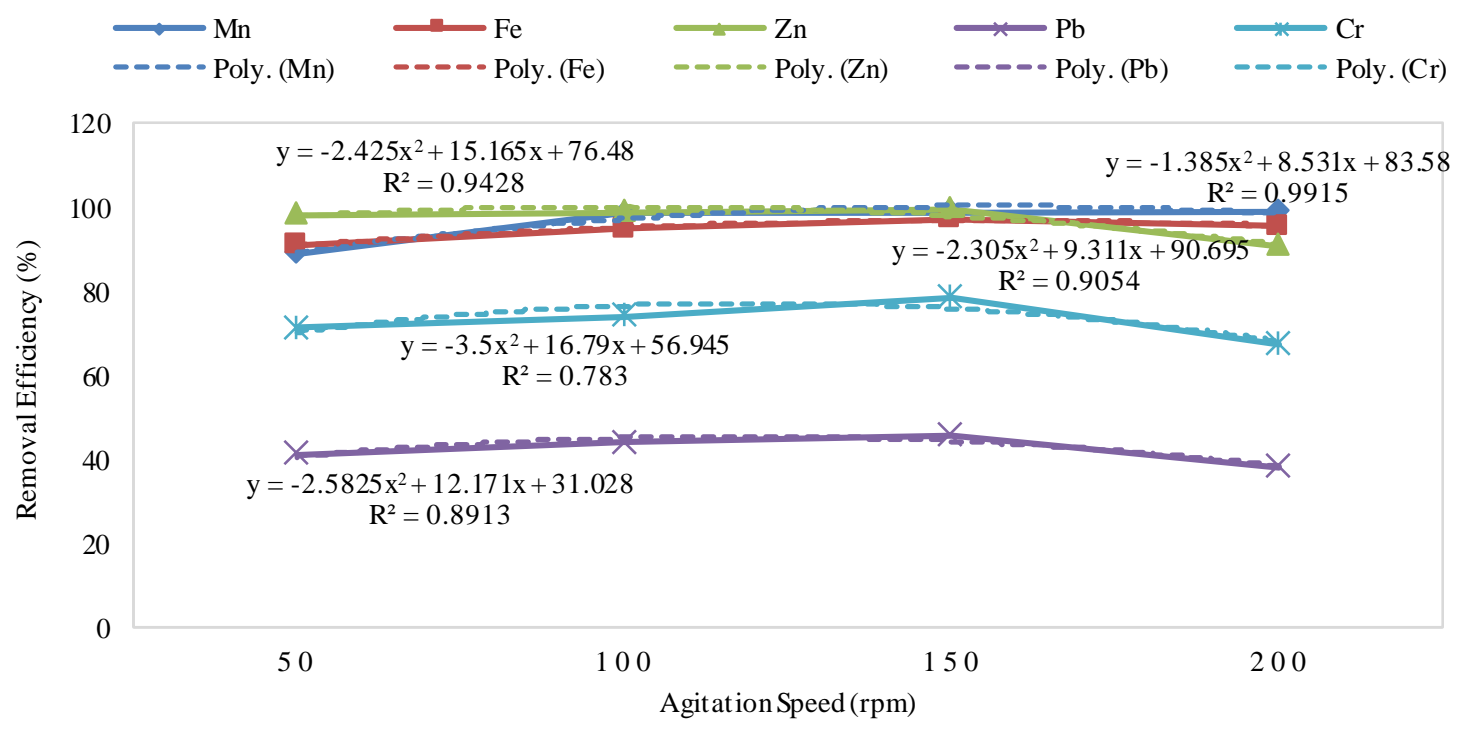

Figure 4. Best fit for the adsorption

\section{CONCLUSION}

Galvanic wastewater is toxic in nature and hence should be adequately treated before discharge. The concentrations of heavy metals $\mathrm{Mn}^{2+}, \mathrm{Fe}^{2+}, \mathrm{Zn}^{2+}, \mathrm{Pb}^{2+}$, $\mathrm{Cr}^{2+}$ in the treated galvanic wastewater are significantly lower than their maximal permissible concentrations after remediation with $\mathrm{CBC}$ as adsorbent. The optimum adsorbent dose for all the metal ions was $0.04 \mathrm{~g} / 100 \mathrm{~mL}$ at an optimum contact time of 60 minutes except for $\mathrm{Fe}^{2+}$ with optimum contact time of 20 minutes, and agitation speed of $150 \mathrm{rpm}$. The maximum metal removal efficiencies obtained were $99.7 \%, 100 \%, 99 \%, 90 \%$ and $85 \%$ for $\mathrm{Mn}^{2+}, \mathrm{Fe}^{2+}, \mathrm{Zn}^{2+}, \mathrm{Pb}^{2+}$ and $\mathrm{Cr}^{2+}$, respectively. The average adsorption capacity for $\mathrm{Mn}^{2+}$ was $0.44 \mathrm{mg} / \mathrm{g}$, $26.7 \mathrm{mg} / \mathrm{g}$ for $\mathrm{Fe}^{2+}, 78.5 \mathrm{mg} / \mathrm{g}$ for $\mathrm{Zn}^{2+}, 0.133 \mathrm{mg} / \mathrm{g}$ for $\mathrm{Pb}^{2+}$ and $10.36 \mathrm{mg} / \mathrm{g}$ for $\mathrm{Cr}^{2+}$. $\mathrm{CBC}$ is an efficient and low cost adsorbent for remediating heavy metals from galvanic wastewater.

\section{REFERENCES}

1. Makisha, N., and Yunchina, M. 2017. "Methods and solut ions for galvanic waste water treatment." MATEC Web of Conferences, 106, pp.07016. https://doi.org/10.1051/matecconf/201710607016
2. Petrov, O., Petrichenko, S., Yushchishina, A., Mitryasova, O., and Pohrebennyk, V. 2020. "Electrospark Method in Galvanic Wastewater Treatment for Heavy Metal Removal." Applied Sciences, 10(5148), pp.2-14. https://doi.org/10.3390/app10155148

3. Innocenzi, V., Cantarini, F., Amato, A., Morico, B., Ippolito, N. M., Beolchini, F., Prisciandaro, M., and Vegliò, F. 2020. "Case study on technical feasibility of galvanic wastewater treatment plant based on life cycle assessment and costing approach." Journal of Environmental Chemical Engineering, 8(6), pp.104535. https://doi.org/10.1016/j.jece.2020.104535

4. Beh, C. L., Chuah, T. G., Nourouzi, M. N., and Choong, T. 2012. "Removal of Heavy Metals from Steel Making Waste Water by Using Electric Arc Furnace Slag." E-Journal of Chemistry, 9(4), pp.2557-2564. https://doi.org/10.1155/2012/128275

5. Berradi, M., Chabab, Z., Arroub, H., Nounah, H., andEl Harfi, A 2014. "Optimization of the coagulation/flocculation process for the treatment of industrial wast ewater from the hot dip galvanizing of steel." Journal of Materials and Environmental Science, 5(2), pp.360-365.

6. Sahoo, P., Das, S. K., and Paulo Davim, J. 2017. "Surface Finish Coatings." In Comprehensive Materials Finishing (pp. 38-55). Elsevier. ht tps://doi.org/10.1016/B978-0-12-803581-8.09167-0

7. Krystal Nanan. 2020. Hot-Dip Vs Cold-Dip Galvanizing: What's the Difference? Retrieved from https://www.corrosionpedia.com/hot-dip-vs-cold-galvanizingwhat s-the-difference/2/6820

8. Tamimi, I., Shaheen, M., Tamimi, Z., and Sawalha, H. 2016. Heavy metal- Wastewater Treatment from Galvanization Industry Using Nanoadsorbent. Published Bachelor Degree in Environmental Technology Engineering, Palestine Polytechnic 
University.

Retrieved

from

http://scholar.ppu.edu/handle/123456789/904

9. Pervov, A. G., Andrianov, A. P., and Yurchevskiy, E. B. 2015 "Principles of utilization of reverse osmosis concentrate at water treatment facilities." Petroleum Chemistry, 55(10), pp.871-878. https://doi.org/10.1134/S0965544115100187

10. Olaoye, R., Afolayan, O., Mustapha, O., and Adeleke, H. 2018 "The Efficacy of Banana Peel Activated Carbon in the Removal of Cyanide and Selected Metals from Cassava Processing Wastewater." Advances in Research, 16(1), pp.1-12. https://doi.org/10.9734/AIR/2018/43070

11. Fitri, R. A., Wirakusuma, A., Fahrina, A., Bilad, M. R., and Arahman, N. 2019. “Adsorption Performance of Low-cost Java Plum Leaves and Guava Fruits as Natural Adsorbents for Removal of Free Fatty Acids from Coconut Oil." International Joumal of Engineering-Transactions A: Basics, 32(10), pp.1372-1378. https://doi.org/10.5829/ije.2019.32.10a.06

12. Shigidi, I., Osman, H., Eldirderi, M., Khan, M. I., Elkhaleefa, A., Dhanapal, D., and Mesfer, M. 2020. "Waste Engine Oil Remediation Using Low Cost Natural Clay Absorbent Material." International Journal of Engineering-Transactions $B$ : Applications, 33(2), pp.178-185. https://doi.org/10.5829/ije.2020.33.02b.01

13. Asemaneh, H. R., Rajabi, L., Dabirian, F., Rostami, N., Derakhshan, A. A., and Davarnejad, R. 2020. "Functionalized Graphene Oxide/Polyacrylonitrile Nanofibrous Composite: $\mathrm{Pb} 2+$ and $\mathrm{Cd} 2+$ Cations Adsorption." International Journal of Engineering-Transactions C: Aspects, 33(6), pp.1048-1053. https://doi.org/10.5829/ije.2020.33.06c.01

14. Olaoye, R. A., Afolayan, O. D., Adeyemi, K. A., Ajisope, L. O., and Adekunle, O. S. 2020. "Adsorption of selected metals from cassava processing wastewater using cow-bone ash." Scientific African, 10 , pp.e00653. https://doi.org/10.1016/j.sciaf.2020.e00653

15. Côrtes, L. N., Druzian, S. P., Streit, A. F. M., Godinho, M., Perondi, D., Collazzo, G. C., Oliveira, M.L. S., Cadaval, T. R. S, and Dotto, G. L. 2019. "Biochars from animal wastes as alternative materials to treat colored effluents containing basic red 9." Joumal of Environmental Chemical Engineering, 7(6), pp.103446. https://doi.org/10.1016/j.jece.2019.103446

16. Lopes, C., Antelo, L. T., Franco-Uría, A., Alonso, A. A., and Pérez-Martín, R. 2015. "Valorisation of fish by-products against waste management treatments - Comparison of environmental impacts." Waste Management, 46, pp.103-112 https://doi.org/10.1016/j.wasman.2015.08.017

17. Inam, E., Edet, J. B., Akpan, P., and Ite, K. 2020 "Characterization and equilibrium studies for the removal of methyleneblue from aqueous solution using activated bone char" Preprint from Research Square. https://doi.org/10.21203/RS.3.RS-21628/V1

18. Jerome Sunday, N. 2019. "Efficiency of Animal (Cow, Donkey, Chicken and Horse) Bones, in Removal of Hexavalent Chromium from Aqueous Solution as a Low Cost Adsorbent." American Journal of Applied Chemistry, 7(1), pp.1-9. https://doi.org/10.11648/j.ajac.20190701.11

19. Bortot Coelho,F. E., Oliveira, V. S., Araújo, E. M. R., Balarini, J. C., Konzen, C., Salum, A., and Miranda, T. L. S. 2021. "Treatment of a wastewater from a galvanizing industry containing chromium(VI) and zinc(II) by liquid surfactant membranes technique." Journal of Environmental Science and Health, Part A $56(3)$, https://doi.org/10.1080/10934529.2020.1871268

pp.289-302.

20. Ajith Kumar, V., Jagadeeshwaran, C., Muralitharan, M., Karthik Raja, N., and Venkatesan,M. A. 2019. "Treatment of galvanized waste water in industry outlet." International Research Joumal of Engineering and Technology, 6(3), pp.8105-8108. Retrieved from www.irjet.net
21. Sawalha, H., Al-Jabari, M., Tamimi, I., Shahin, M., and Tamimi, Z. 2016. "Characterization and Treatment of Wastewater from Galvanization Industry in Palestine Managing heavy metals contaminated industrial wastewater from inorganic chemical industries: Implementing cleaner production for sustainability View project Characteriza." International Journal of Environmental \& Water, 5(3), pp.37-44. Retrieved from https://www.researchgate.net/publication/321391481

22. Akpomie, K. G., Dawodu, F. A., and Adebowale, K. O. 2015. "Mechanism on the sorption of heavy metals from binary-solution by a low cost montmorillonite and its desorption potential." Alexandria Engineering Journal, 54(3), pp.757-767. https://doi.org/10.1016/j.aej.2015.03.025

23. APHA Standard methods for the examination of water and wast ewater, 2005. St andard methods for the examination of water \& wastewater. Washington, DC: American Public Health Association

24. AOAC, 1995. Official methods of analysis, 16th edition Association of Official Analytical Chemists, Inc., Arlington, Virginia, USA.

25. Moreno, J. C., Gómez, R., and Giraldo, L. 2010. "Removal of Mn, $\mathrm{Fe}, \mathrm{Ni}$ and $\mathrm{Cu}$ Ions from Wastewater Using Cow Bone Charcoal." $\quad$ Materials, 3(1), pp.452-466. https://doi.org/10.3390/ma3010452

26. Henry Nwankwo, I., and Nwaiwu, N. 2018. "Production And Characterization Of Activated Carbon From Animal Bone Wastewater treatment View project Production And Characterization Of Activated Carbon From Animal Bone." American Journal of Engineering Research (AJER), 7(7), pp.335341. Retrieved from www.ajer.org

27. Acharya, J., Sahu, J. N., Sahoo, B. K., Mohanty, C. R., and Meikap, B. C. 2009. "Removal of chromium(VI) from wastewater by activated carbon developed from Tamarind wood activated with zinc chloride." Chemical Engineering Journal, 150(1), pp.25-39. https://doi.org/10.1016/j.cej.2008.11.035

28. Gupta, V. K., and Rastogi, A. 2008. "Biosorption of lead from aqueous solutions by green algae Spirogyra species: Kinetics and equilibrium studies.” Journal of Hazardous Materials, 152(1), pp.407-414. https://doi.org/10.1016/j.jhazmat.2007.07.028

29. Li, Y., Du, Q., W ang, X., Zhang, P., Wang, D., Wang, Z., and Xia, Y. 2010. "Removal of lead from aqueous solution by activated carbon prepared from Enteromorpha prolifera by zinc chloride activation." Journal of Hazardous Materials, 183(1-3), pp.583589. https://doi.org/10.1016/j.jhazmat.2010.07.063

30. Mohammadi, S. Z., Karimi, M. A., Afzali, D., and Mansouri, F 2010. "Removal of $\mathrm{Pb}$ (II) from aqueous solutions using activated carbon from Sea-buckthorn stones by chemical activation." Desalination 262(1-3), pp.86-93. https://doi.org/10.1016/j.desal.2010.05.048

31. Depci, T.,Kul, A. R., and Önal, Y. 2012. "Competitive adsorption of lead and zinc from aqueous solution on activated carbon prepared from Van apple pulp: Study in single- and multi-solute systems." Chemical Engineering Journal, 200-202, pp.224-236. https://doi.org/10.1016/j.cej.2012.06.077

32. Huang, Y., Li, S., Chen, J., Zhang, X., and Chen, Y. 2014 "Adsorption of $\mathrm{Pb}$ (II) on mesoporous activated carbons fabricated from water hyacinth using H3PO4 activation: Adsorption capacity, kinetic and isotherm studies." Applied Surface Science, 293, pp.160-168. https://doi.org/10.1016/j.apsusc.2013.12.123

33. Ushakumary E.R 2013. Waste water treatment using low cost nat ural adsorbents, $\mathrm{PhD}$ Thesis, Cochin University of Science and Technology, India.

34. Aziz, A., Latiff, A., Abdulrahman, A., Daud, Z., Ridzuan, B., Falilah, N., and Daud, M. 2016. "batch adsorption of manganese from palm oil mill effluent onto activated cow bone powder." ARPN Journal of Engineering and Applied Sciences, 11(4), pp.2627-2631. Retrieved from www.arpnjournals.com 
35. Ezeh, K., Ogbu, ; I C, Akpomie, ; K G, Ojukwu, ; N C, and Ibe, J. C. 2017. "Utilizing the Sorption Capacity of Local Nigerian Sawdust for Attenuation of Heavy Metals from Solution: Isotherm, Kinetic, and Thermodynamic Investigations." The Pacific Journal of Science and Technology, 18(1), pp.251-264. Retrieved from http://www.akamaiuniversity.us/PJST.htm

36. Putro, R. K. H., Rahardi, V. N., Cahyonugroho, O. H., and Amalia, A. 2018. " $\mathrm{Cr}$ (VI) Removal Using Cow Bone Waste Adsorbent." In Proceedings of the International Conference on Science and Technology (ICST 2018). Paris, France: Atlantis Press. https://doi.org/10.2991/icst-18.2018.48

37. Kumbasar, R. A. 2008. "Studies on extraction of chromium (V) from acidic solutions containing various metal ions by emulsion liquid membrane using Alamine 336 as extractant." Journal of Membrane Science, 325(1), pp.460-466. https://doi.org/10.1016/j.memsci.2008.08.009

38. Fournier-Salaün, M. C., and Vauclair, C. 2002. "Recovery of chromique ions from aqueous effluents by liquid membrane in continuous mode." Desalination, 144(1-3), pp.227-229. https://doi.org/10.1016/S0011-9164(02)00316-8

39. Fuller, E. J., and Li, N. N. 1984. "Extraction of chromium and zinc from cooling tower blowdown by liquid membranes." Joumal of Membrane Science, 18, pp.251-271. https://doi.org/10.1016/S0376-7388(00)85038-3

40. Ogbozige, F. ., and T oko, M. A. 2020. "Adsorption Isotherms and Kinetics of Lead and Cadmium Ions: Comparative Studies Using Modified Melon (Citrullus colocynthis) Husk." Iranian Joumal of Energy and Environment, 11(2), pp.157-162. https://doi.org/10.5829/IJEE.2020.11.02.10

41. Ramezani, G., S., E. M., and Emadi, M. 2020. "Removal of Pb ${ }^{2+}$ Ions from Aqueous Solutions by Modified Magnetic Graphene Oxide: Adsorption Isotherms and Kinetics Studies." Iranian Journal of Energy and Environment, 11(4), pp.277-286. https://doi.org/10.5829/IJEE.2020.11.04.05

\section{COPYRIGHTS}

(C2021 The author(s). This is an open access article distributed under the terms of the Creative Commons Attribution (CC BY 4.0), which permits unrestricted use, distribution, and reproduction in any medium, as long as the original authors and source are cited. No permission is required from the authors or the publishers.

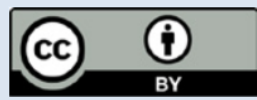

ثابت شده است كه حسبندگى يونهاى فلزى از فاضلاب به سطح يك ماده در فرآيند جذب براى تصفيه فاضلاب قبل از تخليه مؤثر است. در فزايند جذب براى

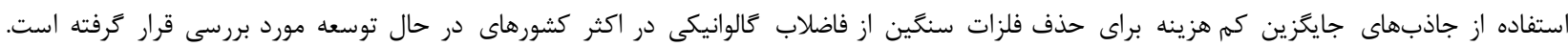

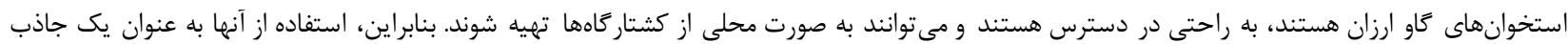

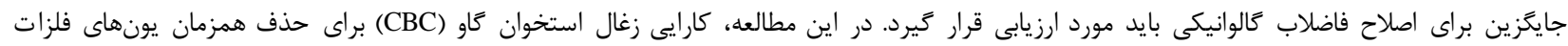

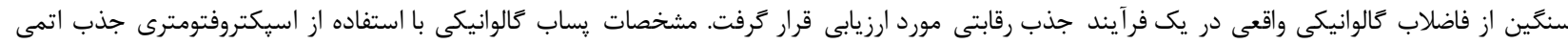

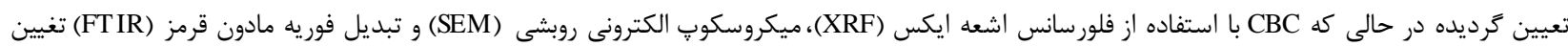

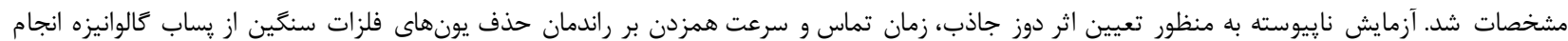
شد. غلظت

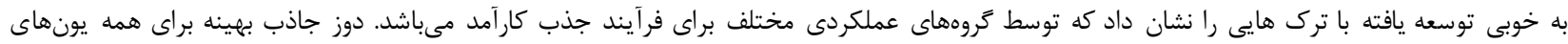

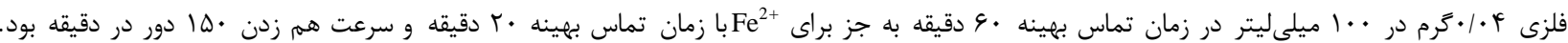

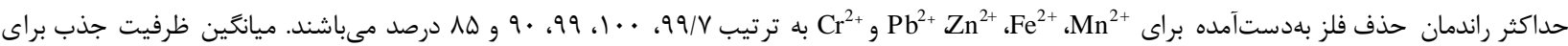

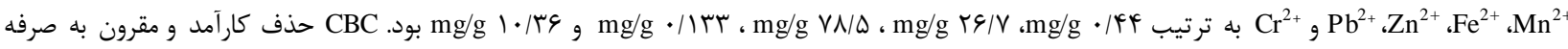

$$
\text { يونهاى فلزى انتخاب شده از فاضلاب كالوانيزه را ارائه مىدهد. }
$$

